Review

\title{
Supercritical Carbon Dioxide Extraction of Carotenoids from Pumpkin (Cucurbita spp.): A Review
}

\section{Miriana Durante $^{1, *}$, Marcello Salvatore Lenucci ${ }^{2}$ and Giovanni Mita ${ }^{1}$}

1 Istituto di Scienze delle Produzioni Alimentari-Consiglio Nazionale delle Ricerche (ISPA-CNR), Via Prov. le Lecce-Monteroni, Lecce 73100, Italy; E-Mail: giovanni.mita@ispa.cnr.it

2 Dipartimento di Scienze e Tecnologie Biologiche ed Ambientali (Di.S.Te.B.A.), Università del Salento, Via Prov. le Lecce-Monteroni, Lecce 73100, Italy;

E-Mail: marcello.lenucci@unisalento.it

* Author to whom correspondence should be addressed; E-Mail: miriana.durante@ispa.cnr.it; Tel.: +39-0832-422-634; Fax: +39-0832-422-620.

Received: 10 March 2014; in revised form: 1 April 2014 / Accepted: 1 April 2014 /

Published: 21 April 2014

\begin{abstract}
Carotenoids are well known for their nutritional properties and health promoting effects representing attractive ingredients to develop innovative functional foods, nutraceutical and pharmaceutical preparations. Pumpkin (Cucurbita spp.) flesh has an intense yellow/orange color owing to the high level of carotenoids, mainly $\alpha$-carotene, $\beta$-carotene, $\beta$-cryptoxanthin, lutein and zeaxanthin. There is considerable interest in extracting carotenoids and other bioactives from pumpkin flesh. Extraction procedures able to preserve nutritional and pharmacological properties of carotenoids are essential. Conventional extraction methods, such as organic solvent extraction (CSE), have been used to extract carotenoids from plant material for a long time. In recent years, supercritical carbon dioxide $\left(\mathrm{SC}-\mathrm{CO}_{2}\right)$ extraction has received a great deal of attention because it is a green technology suitable for the extraction of lipophylic molecules and is able to give extracts of high quality and totally free from potentially toxic chemical solvents. Here, we review the results obtained so far on $\mathrm{SC}-\mathrm{CO}_{2}$ extraction efficiency and quali-quantitative composition of carotenoids from pumpkin flesh. In particular, we consider the effects of (1) dehydration pre-treatments; (2) extraction parameters (temperature and pressure); the use of water, ethanol and olive oil singularly or in combination as entrainers or pumpkin seeds as co-matrix.
\end{abstract}


Keywords: carotenoids; conventional solvent extraction; co-matrix; co-solvent; Cucurbita spp. modifier; supercritical carbon dioxide

\section{Introduction}

Carotenoids are largely used in food preparation to make product color appealing to consumers. They represent a group of bioactive compounds responsible for the yellow-red pigmentation of many plant organs and plant derived raw and processed foods, known to improve food healthiness and stability because of their pro-vitamin A activity, antioxidant power and boost of cell-mediated and humoral immune response [1,2].

Of the more than 700 natural carotenoids identified up to now, about 50 could potentially be absorbed, transported, delivered to tissues, metabolized and, eventually, used by the human body. The number is reduced to six ( $\alpha$-carotene, $\beta$-carotene, lycopene, lutein, zeaxanthin and $\beta$-cryptoxanthin) considering only those effectively detected in blood plasma and tissues of people from different countries and associated with some health benefits $[3,4]$.

The Mediterranean diet offers a high amount and a wide diversity of carotenoids due to the regular intake of fruit and vegetables. Tomato, green leafy vegetables (spinach, broccoli, endive, lettuce, etc.) cereals and red-pepper are the main sources of lycopene, lutein, zeaxanthin and $\beta$-cryptoxanthin, respectively. While $\alpha$-carotene and $\beta$-carotene are taken up mainly by the consumption of carrot, sweet potato and pumpkin [4].

Pumpkin is thought to be native of the South America; it belongs to the genus Cucurbita of the Cucurbitaceae family. C. moschata, C. maxima and C. pepo, are three of the most cultivated species world-wide [5]. They are frequently consumed cooked as a main course or side dish, and used, as an ingredient, in pies, soups, stews, and bakery preparations [6,7]. Pumpkin is also popular in traditional medicine for several ailments (antidiabetic, antihypertensive, antitumor, immunomodulation, antibacterial, antihypercholesterolemia, intestinal antiparasitia, antiinflammation, antalgic) [8]. The presence of many biologically active components including high levels of $\alpha$ - and $\beta$-carotene, $\beta$-cryptoxanthin, lutein and zeaxanthin, polysaccharides, phytosterols, unsaturated fatty acids, proteins and peptides makes pumpkin extremely attractive for the phytochemical manufacturing industry $[9,10]$.

Different technological approaches have been developed to extract bioactive molecules from pumpkin, especially oil and proteins from seeds [11]. Conventional solvent extraction (CSE) and supercritical $\mathrm{CO}_{2}\left(\mathrm{SC}-\mathrm{CO}_{2}\right)$ extraction were reported to be effective methods to produce pumpkin seed oils, with the latter being particularly convenient to obtain solvent-free extracts with unaltered pharmacological activities [12]. In the last five years, several papers have focused on carotenoid extraction from pumpkin flesh, expanding the potential use of the fruit mesocarp previously proposed exclusively as a source of cell wall polysaccharides such as pectins $[13,14]$. These studies investigated the effects of extraction parameters and plant material pretreatments (dehydration, granulometry, etc.) on carotenoid yield and composition [15-18].

Large scale carotenoid extraction from ripe pumpkin fruits could give a product useful as ingredient for functional food, cosmeceutical and pharmaceutical preparations. Traditionally, CSE use $n$-hexane, 
propanol, methanol, tetrahydrofuran or ethyl acetate to extract carotenoids $[19,20]$. This method usually requires long extraction time, large amounts of organic solvent and high temperatures which could lead to extensive degradation of thermo-sensible molecules such as carotenoids and often leave trace amounts of potentially toxic solvent in the extract [21-23].

$\mathrm{SC}-\mathrm{CO}_{2}$ extraction technology has been widely used as an alternative to CSE for the extraction of natural products because it gives extracts totally free of organic solvents [24,25]. As a solvent, $\mathrm{CO}_{2}$ is non-toxic, non-flammable, readily available, low cost and exhibits high selectivity as a result of low viscosity, high diffusivity and liquid-like density [26,27]. In addition, $\mathrm{CO}_{2}$ has a low critical temperature and pressure $\left(31^{\circ} \mathrm{C}\right.$ and 74 bar, respectively) which makes it the ideal solvent for the extraction of thermo-sensitive molecules such as carotenoids [28]. Many studies have been conducted to investigate the applicability of $\mathrm{SC}-\mathrm{CO}_{2}$ for the extraction of bioactive compounds [29,30] and several authors focused their research on the carotenoid extraction from a wide range of plant material such as leaf protein concentrates [31], paprika [32], sweet potato [33], tomato [34], watermelon [35] and wheat bran $[25,36]$.

In a recent paper, the chemical, nutritional and technological aspects of pumpkin as a source of bioactive molecules, as well as the health-benefits associated with its consumption have been reviewed [37]. Here, we summarize the most recent findings related to carotenoid extraction from pumpkin flesh with an emphasis on $\mathrm{SC}-\mathrm{CO}_{2}$ extraction and related issues such as pumpkin flesh dehydration, matrix granulometry, use of entrainers or co-matrices.

\section{2. $\left(\mathrm{SC}-\mathrm{CO}_{2}\right)$ Extraction of Carotenoids from Pumpkin}

\subsection{Effect of Pre-Treatment}

Drying is one of the most ancient methods to preserve or process food, including fruits and vegetables. Dried vegetable powders are often incorporated in food products (soups, noodles, bread, cakes and pasta) to improve their flavor and nutritional value [38].

Recently, dehydration gained great attention especially in industrial processes that use $\mathrm{SC}-\mathrm{CO}_{2}$ to extract phytochemicals. The high water content of many plant tissues and organs is detrimental to the efficient extraction of lipophilic nutraceuticals with $\mathrm{SC}-\mathrm{CO}_{2}$. Being polar and scarcely soluble in $\mathrm{SC}-\mathrm{CO}_{2}$, water hinders the fluid flow through the plant tissues reducing the contact surface between solutes and solvent and increasing the diffusion resistance of solutes [18,24,39]. It also leads to problems such as restrictor or valve clogging due to ice formation and difficulties in removal of water from the extracts $[40,41]$. Moisture reduction is, hence, a prerequisite to improve the yield and quality of $\mathrm{SC}-\mathrm{CO}_{2}$ extracted liposoluble molecules from plant tissues. It is known that moisture content, within certain percentages, influence $\mathrm{SC}-\mathrm{CO}_{2}$ extraction of lipophilic molecules [42].

Hot air- [43], oven- [44-46], freeze- [44,47,48], convective- [44,49-51], microwave- [52,53], and osmotic- [54-56] drying methods, as well as combined treatments such as microwave-air [53] and vacuum-microwave [44], have been assessed for pumpkin flesh dehydration, and their effects on drying kinetics, chemical properties (moisture, ash, total and reducing sugars, fibers, proteins, lipids, and isoprenoids), texture and color of the final products have been investigated $[7,16,47]$. 
Due to its affordability, oven-drying is the most common dehydration process, but it often leads to the degradation of thermolabile compounds and/or oxidizable substrates such as carotenoids, tocochromanols and lipids. It is known that high temperature may alter the chemical composition, the color, the nutritional value and the organoleptic quality of the dried product. Color changes have been related to carotenoids degradation during pumpkin heat processing [43,57]. Nevertheless, only a few papers report data on the carotenoid composition of dehydrated pumpkin flesh (Table 1). Using conventional solvent extraction techniques, Wang et al. [43] found that hot-air treatment $\left(70{ }^{\circ} \mathrm{C}\right)$ of pumpkin flesh slices (C. maxima), with 9.3\% residual moisture, determined a strong reduction (65\%) of total carotenoid content with respect to raw pumpkin $(67.6 \mathrm{mg} / 100 \mathrm{~g})$. In order to overcome these limitations, oven-drying is generally carried out under vacuum, at moderate temperature $\left(40-60{ }^{\circ} \mathrm{C}\right)[44,45]$ or replaced by freeze-drying $[45,48]$ which preserves, almost unaltered, the physico-chemical characteristics and quality of the raw plant material [45]. However, the high cost of this process is a major drawback of this method, justified only for extracts with high commercial value [58]. Dirim and Çalıskan [38] obtained a freeze-dried pumpkin matrix (C. moschata), with a residual moisture of $3.9 \%$ and total carotenoid content $[0.7 \mathrm{mg} / 100 \mathrm{~g}$ dry matter (d.m.) ] approximately $26 \%$ lower than that of the fresh material $(1.1 \mathrm{mg} / 100 \mathrm{~g} \mathrm{~d} . \mathrm{m}$.). An approximately $6 \%$ reduction of total carotenoids, with respect to raw pumpkin, was reported by Wang et al. [43] in freeze-dried pumpkin slices with a residual moisture of $10.9 \%$. Nawirska et al. [45] evaluated the total carotenoid content of dried slices of 12 pumpkin (C. maxima and C. pepo) cultivars, the highest average total carotenoid content was obtained from freeze-dried samples $(160 \mathrm{mg} / 100 \mathrm{~g} \mathrm{~d} . \mathrm{m}$.), followed by vacuum microwave (130 mg/100 g d.m.) and by convective-drying (5 mg/100 g d.m.). More specifically, Durante et al. [16] compared the effects of vacuum oven- and freeze-drying methods on carotenoids concentration in a dehydrated pumpkin matrix. Oven- and freeze-dried pumpkin had a residual moisture of approximately $8 \%$ and $12 \% w / w$, respectively (Table 1 ). No statistically significant difference in total carotenoid yields was observed between oven- or freeze-dried matrices ( 81.3 vs. $73.7 \mathrm{mg} / 100 \mathrm{~g}$ d.m., respectively). Wang et al. [43] proposed a dehydration method based on treatment of pumpkin slices with a red algae extract (RAE) at 40\% (w/w), a promising new dehydrating agent. They found that RAE-treated samples had a residual moisture of $7.8 \%$ and a total carotenoid content approximately $15 \%$ lower than that measured in raw pumpkin and considerably higher than in hot air-dried pumpkin slices.

In studies conducted on the SC- $\mathrm{CO}_{2}$ extraction of carotenoids from pumpkin (Table 2), Shi et al. [17] used freeze-dried C. moschata flesh matrix, containing a $10 \%$ residual moisture, to feed the extractor, getting a maximum carotenoid yield of about $10.9 \mathrm{mg} / 100 \mathrm{~g} \mathrm{~d} . \mathrm{m}$. The same authors, using freeze-dried matrix from C. maxima obtained a carotenoid amount of $132.2 \mathrm{mg} / 100 \mathrm{~g}$. Conversely, Durante et al. [16] reported that total carotenoid yield obtained by $\mathrm{SC}-\mathrm{CO}_{2}$ from oven-dried pumpkin flesh (C. moschata) was about 8.5 fold higher than from freeze-dried sample $(49.2$ vs. $5.8 \mathrm{mg} / 100 \mathrm{~g} \mathrm{d.m.,} \mathrm{respectively).}$ The higher carotenoid yield, obtained from oven-dried matrix, was hypothesized to be due to the prolonged heat treatment on plant tissue and cell structure such as cell membranes and chloroplasts that might cause the disaggregation and cell wall loosening, and a consequent increase in the permeability of the matrix to the fluid, as also suggested by Gutiérrez et al. [59] and Snyder et al. [60]. Furthermore, it has been reported that freeze-drying may strengthen tissue aggregation leading to a decrease in solute-solvent contact surface which negatively affects extraction yields [61,62]. 
The amount of carotenoids extracted by $\mathrm{SC}-\mathrm{CO}_{2}$ is also affected by the particle size of the dried sample. Generally, the smaller the particle size, the higher the amount of extracted carotenoids [63]. This is due to the higher surface to volume ratio of smaller particles and to a reduction of the path length that analytes must diffuse through to reach the bulk phase $[64,65]$. On the other hand, the use of very small particles could be detrimental. They can excessively compact the extraction bed, increasing the internal mass transfer resistance and causing channeling effects [66]. To our knowledge, there are no substantial data about the effect of particle size on carotenoid extraction from dried pumpkin flesh. Durante et al. [16] carried out $\mathrm{SC}-\mathrm{CO}_{2}$ extraction of carotenoids from pumpkin on samples with a particle size of $250 \mu \mathrm{m}$, corresponding to 70 mesh, while Shi et al. [17,18] used samples milled to a size of $1 \mathrm{~mm}$, corresponding to $18 \mathrm{mesh}$, however, because of the extensive differences in matrix pre-treatment and extraction parameters the results are hardly comparable.

\subsection{Effects of Temperature and Pressure}

Supercritical fluid extraction solubility and selectivity depend greatly on the equilibrium between fluid density and solute vapor pressure which are affected by temperature and pressure. Generally, at constant pressure, the increase of temperature reduces the density of $\mathrm{SC}-\mathrm{CO}_{2}$ thus reducing its solvating power, but it enhances the vapor pressure of extractable compounds, consequently increasing analyte solubility and extraction yield [66]. At constant temperature, the fluid density increases with increasing pressure and, accordingly, increases the solubility of the analyte [67].

Table 3 summarizes the findings regarding the effect of temperature and pressure on carotenoids composition extracted by $\mathrm{SC}-\mathrm{CO}_{2}$ from pumpkin flesh.

Shi et al. [17] utilized different temperatures from 40 to $70{ }^{\circ} \mathrm{C}$ and pressures from 25 to $35 \mathrm{MPa}$ in $\mathrm{SC}-\mathrm{CO}_{2}$ extraction of carotenoids from pumpkin (Table 3 ). They found that carotenoid yield increased with increasing pressure and temperature. The highest extraction yield (6.1 mg/100 g matrix d.m.) was obtained at $70{ }^{\circ} \mathrm{C}$ and $35 \mathrm{MPa}$ and highlighted the importance of the interaction of the two parameters in affecting $\mathrm{SC}-\mathrm{CO}_{2}$ extraction of carotenoids from pumpkin matrices.

A particularly important effect of temperature regards the isomerization and degradation of extracted plant carotenoids. In plant tissues most carotenoids occur naturally as all- $E$-isomers which can be easily isomerized to $Z$-isomers when exposed to heat and light. It has been reported that the increase in extraction temperature over $80{ }^{\circ} \mathrm{C}$ is accompanied by carotenoids isomerization and degradation [24,68]. Shi et al. [17] observed that in $\mathrm{SC}-\mathrm{CO}_{2}$ pumpkin extracts, when the extraction temperature was raised from 40 to $70{ }^{\circ} \mathrm{C}$, the $(9+13)-Z$ - $\beta$-carotene isomers increased significantly from $10.3 \%$ to $12.7 \%$ at $25 \mathrm{MPa}$ and from $8.0 \%-12.5 \%$ at $35 \mathrm{MPa}$ (Table 3). Shi et al. [18] found that when the extraction temperature was increased from 50 to $80{ }^{\circ} \mathrm{C}$ at a constant pressure of $25 \mathrm{MPa}$, carotenoid yield decreased from 132.2 to $44.6 \mathrm{mg} / 100 \mathrm{~g} \mathrm{~d} . \mathrm{m}$. and the ratios of $Z$ - $\beta$-carotene/total carotenoids increased from $13.7 \%$ to $24.5 \%$. Durante et al. [16] reported that, at $35 \mathrm{MPa}$ and $60{ }^{\circ} \mathrm{C}$, $\mathrm{SC}-\mathrm{CO}_{2}$ extraction of oven-dried pumpkin matrix gave an extract in which $Z$-isomers (represented only by $13-Z-\beta$-carotene) contributed to approximately $9.3 \%$ to the total carotenoid amount.

Although $\mathrm{SC}-\mathrm{CO}_{2}$ flow-rate is an important parameter affecting $\mathrm{SC}-\mathrm{CO}_{2}$ carotenoid extraction, no literature data have been available for pumpkin so far. 


\subsection{Effects of Entrainers and Co-Matrices}

Pure SC- $\mathrm{CO}_{2}$ has good solvent properties for extraction of non-polar and moderately polar compounds which can be suitably tailored by varying temperature and pressure. To extend $\mathrm{SC}-\mathrm{CO}_{2}$ solvating power, improve its affinity for poorly soluble solutes and, ultimately, increase the extraction yield, small volumes of entrainers (modifier or co-solvents) such as water, methanol, ethanol, hexane, etc., are often added. The chemical features of modifiers and their concentration within the supercritical fluid are the key parameters affecting solubility of a target solute, nevertheless the physical structure of the solid matrix (granulometry, hydration, packing density), as well as its chemical composition, must be taken into account to obtain good extraction yields [69]. Entrainers could be constantly added to the $\mathrm{CO}_{2}$ mobile phase upstream of extraction vessel (co-solvent) or, alternatively, mixed with the matrix powder into the extractor vessel (modifier). In the latter case, modifiers, depending on their solubility in $\mathrm{SC}-\mathrm{CO}_{2}$, can be quickly transported out of the extractor by the supercritical fluid with the consequent loss of their positive effects. In order to overcome this limitation, co-extraction procedures consisting in blending the matrix with appropriate co-matrices naturally providing the entrainer (usually a vegetable oil) have been successfully developed [70-73].

Table 3 reports the data published so far on the effect of entrainers or co-matrix addition on total yield and composition of carotenoid extracts obtained from pumpkin by $\mathrm{SC}-\mathrm{CO}_{2}$ extraction.

Investigating the effects of water, ethanol or olive oil added as modifiers for $\mathrm{SC}-\mathrm{CO}_{2}$ extraction of carotenoids from pumpkin flesh, Shi et al. [17,18] found that most of them, used either alone or in combinations, had significant effects on both yield improvement and composition of carotenoid extracts (Table 3). Temperature strongly affected carotenoid yields since, as reported by Shi et al. [17], there is a clear improvement at $70{ }^{\circ} \mathrm{C}$ with respect to $40{ }^{\circ} \mathrm{C}$. Furthermore, a reduction in carotenoid yield was observed at $80{ }^{\circ} \mathrm{C}$, confirming that this could be considered a limit temperature inducing thermal denaturation of extracts [18].

Regardless of temperature the effect of single modifier on the extraction yield followed the order: olive oil $>$ ethanol $>$ water. While the highest yield was obtained at $50{ }^{\circ} \mathrm{C}$ using $10 \%$ ethanol $+10 \%$ oil as modifier.

Relatively low water contents $(5 \%$ and $10 \%)$ were not effective in increasing total carotenoid yield at extraction temperature of $50{ }^{\circ} \mathrm{C}$, however $15 \%$ water improved the carotenoid extraction of 1.35 -fold. As previously stated (see Section 2.1), excess of water is generally detrimental for $\mathrm{SC}-\mathrm{CO}_{2}$ extraction of lipophilic compounds. Water polarity reduces the solvating power of $\mathrm{SC}-\mathrm{CO}_{2}$ towards relatively non-polar carotenoids; besides it often causes mechanical problems due to ice formation [74]. Nevertheless, its positive effect in matrix swelling may facilitate $\mathrm{CO}_{2}$ diffusion through the sample and enhance carotenoid extraction. Swelling behavior is mainly controlled by temperature, this could explain the differences observed at $80{ }^{\circ} \mathrm{C}$ operating temperature. In this case, the tendency was the opposite, the higher the water content the lower the yield improvement [18]. The presence of polar co-solvents such as ethanol or methanol increases the polarity of the medium and simultaneously increases the overall recovery yield of polar molecules. Ethanol has been broadly used as a co-solvent in extraction of bioactive compounds due to its low toxicity compared to other solvents [75-77]. Shi et al. [18] observed that the effect of ethanol was greater than that of water on carotenoid yield at both temperatures $\left(50,80^{\circ} \mathrm{C}\right)$ assayed, because the addition of ethanol increased the bulk density of 
$\mathrm{SC}-\mathrm{CO}_{2}$ due to the high density of the co-solvent and clustering of $\mathrm{SC}-\mathrm{CO}_{2}$ molecules around the co-solvent [78]. These results are in agreement with the previous findings of the same research group [17] who reported that the use of $10 \%$ ethanol as modifier doubled carotenoid extraction yield from pumpkin flesh.

In some reports, vegetable oils were used as modifier. Sun and Temelli [79] found that the use of canola oil increased SC- $\mathrm{CO}_{2}$ extraction yield of carotenoids from carrots. This is possibly due to the interaction of canola oil with the matrix, thus facilitating the solubilization of carotenoids, or swelling of the matrix. Shi et al. [18] reported that olive oil enhanced the extraction yield by increasing the solubility of $\alpha$-carotene, $\beta$-carotene, $(9+13-Z)-\beta$-carotene, lutein and lutein esters in the modified supercritical fluid. When a mixture of two modifiers was used, carotenoid yield was even higher than that obtained using equivalent amounts of single modifiers. Such enhancement increased with the increasing amount of both ethanol and olive oil (either at 50 or $80{ }^{\circ} \mathrm{C}$ ). The results obtained at $50{ }^{\circ} \mathrm{C}$ showed that the combination of modifiers on the total carotenoids yield followed the order: water/oil $>$ ethanol/oil $>$ water/ethanol, while at $80{ }^{\circ} \mathrm{C}$ the combination of modifier on the total carotenoid yield followed the order: oil/ethanol $>$ water/oil $>$ water/ethanol. Olive oil (-COOR) has $\mathrm{H}$-bonding ability, which could link to ethanol and contribute to the interaction between modified $\mathrm{SC}-\mathrm{CO}_{2}$ and the analyte improving the solubility of carotenoids. Furthermore, the addition of modifiers increased the antioxidant activities of the extracts probably due to the percentage of polar and non-polar compounds extracted by $\mathrm{SC}-\mathrm{CO}_{2}$. Several studies indicate that $\beta$-carotene and $\alpha$-tocopherol act synergistically and $\alpha$-tocopherol protects $\beta$-carotene from oxidation [80-82].

Shi et al. [18] described that the modifier and the operating temperature notably influenced the ratio of $Z$ - $\beta$-carotene/total carotenoids extracted by $\mathrm{SC}-\mathrm{CO}_{2}$. The antioxidant activity did not show a linear correlation with the total yield of carotenoids, it could be related to the proportion of all- $E$ form and $Z$-isomers present in extracts, as well as the ratio of different type $Z$-isomers, such as 5 -Z- $\beta$-carotene, $9-Z-\beta$-carotene and $13-Z-\beta$-carotene, because some reports indicated that $Z$-forms of carotenoids had higher antioxidant activity compared to that of all-E- $\beta$-carotene [83-85].

Durante et al. [16] used milled pumpkin seeds as co-matrix and demonstrated that pumpkin seeds contributed to enhance the carotenoid extraction efficiency possibly by increasing the solubility of carotenoids in the $\mathrm{CO}_{2}$ and/or the fluid flow rate of carotenoids through the matrix and pipelines (Table 3). Moreover, the addition of pumpkin seeds to the pumpkin matrix led to an enrichment of the extract in Vitamin E and polyunsaturated fatty acids.

\subsection{Comparison of Carotenoid Composition Extracted from Pumpkin by Organic Solvent and $\mathrm{SC}_{-} \mathrm{CO}_{2}$}

Conventional solvent extraction (CSE) has been widely used to extract bioactive compounds from plants. Despite its numerous drawbacks, including long extraction time and consumption of large amounts of potentially toxic solvents, CSE is often used as benchmark for other extraction methods. $\mathrm{CSE}$ and $\mathrm{SC}-\mathrm{CO}_{2}$ carotenoid extraction efficiency from pumpkin flesh and carotenoid profile of extracts have been recently compared [16-18]. Table 4 reports the composition of carotenoids extracts obtained from pumpkin by both CSE and SC-CO 2 .

Shi et al. [17] obtained the highest total carotenoids yield from ripe pumpkin (C. moschata) using ethanol/hexane $(1: 1 \mathrm{v} / \mathrm{v})$, lower yields were obtained by $\mathrm{SC}-\mathrm{CO}_{2}$ extraction at $70{ }^{\circ} \mathrm{C}$ and at $40{ }^{\circ} \mathrm{C}$ with 
or without the addition of ethanol, as modifier (Table 4). Total carotenoid amounts extracted from C. moschata were lower than those described by Durante et al. [16] possibly depending on several factors such as genotype, pedoclimatic conditions, variation in harvesting time, post harvesting storage, matrix preparation, etc. However, also in this study, the amount of carotenoids obtained after hexane extraction, from pumpkin matrix, was about 1.6-fold higher than those obtained after $\mathrm{SC}-\mathrm{CO}_{2}$. The addition of milled pumpkin seeds to the matrix contributed to enhance carotenoid extraction by $\mathrm{SC}-\mathrm{CO}_{2}$, in fact, in these experimental conditions the amount of carotenoids extracted by either hexane and $\mathrm{SC}-\mathrm{CO}_{2}$ were not significantly different [16].

Shi et al. [17] described that lutein and lutein esters, lycopene and the total amount of 9-Z and $13-Z$ - $\beta$-carotene were higher inSC- $\mathrm{CO}_{2}$ extracts obtained at $70{ }^{\circ} \mathrm{C}$ (using etanol as modifier) than in CSE extracts and similar results were obtained by Shi et al. [18].

Table 1. Carotenoid composition of dehydrated pumpkin flesh by conventional solvent extraction.

\begin{tabular}{|c|c|c|c|c|c|}
\hline \multirow[b]{2}{*}{ Reference } & \multicolumn{4}{|c|}{ Extraction conditions } & \multirow{2}{*}{$\begin{array}{c}\text { Total } \\
\text { carotenoids } \\
(\mathrm{mg} / \mathbf{1 0 0} \mathrm{g} \mathrm{d.m.})\end{array}$} \\
\hline & $\begin{array}{l}\text { Pumpkin } \\
\text { species }\end{array}$ & $\begin{array}{l}\text { Drying } \\
\text { methods }\end{array}$ & $\begin{array}{c}\text { Residual moisture } \\
(\%, w / w)\end{array}$ & Extraction methods & \\
\hline \multirow{3}{*}{$\begin{array}{l}\text { Nawirska } \\
\text { et al. [44] }\end{array}$} & $\begin{array}{l}\text { C. maximal } \\
\text { C. pepo }\end{array}$ & $\begin{array}{l}\text { Vacuum } \\
\text { microwave }\end{array}$ & - & Acetone $80 \%(v / v)$ & 130 \\
\hline & $\begin{array}{l}\text { C. maximal } \\
\text { C. pepo }\end{array}$ & Convective & - & Acetone $80 \%(v / v)$ & 5 \\
\hline & $\begin{array}{l}\text { C. maximal } \\
\text { C. pepo }\end{array}$ & Freeze-drying & - & Acetone $80 \%(v / v)$ & 160 \\
\hline \multirow{3}{*}{$\begin{array}{l}\text { Wang } \\
\text { et al. }[43]\end{array}$} & C. maxima & Hot-air & 9.3 & Acetone $100 \%(v / v)$ & 67.6 \\
\hline & C. maxima & Freeze-drying & 10.9 & Acetone $100 \%(v / v)$ & 63.7 \\
\hline & C. maxima & $\operatorname{RAE}(40 \%) *$ & 7.8 & Acetone $100 \%(v / v)$ & 57.4 \\
\hline $\begin{array}{c}\text { Dirim and } \\
\text { Çalıskan [38] }\end{array}$ & C. moschata & Freeze-drying & 3.9 & $\begin{array}{c}\text { Hexane/acetone/ethanol } \\
(50 / 25 / 25, v / v / v)\end{array}$ & 0.7 \\
\hline Durante & C. moschata & Vacuum oven & 12 & Hexane $100 \%(v / v)$ & 81.3 \\
\hline et al. [16] & C. moschata & Freeze-drying & 8 & Hexane $100 \%(v / v)$ & 73.7 \\
\hline
\end{tabular}

* RAE, red algae extract.

Table 2. Effect of pre-treatment on carotenoid extracts from pumpkin by $\mathrm{SC}-\mathrm{CO}_{2}$.

\begin{tabular}{|c|c|c|c|c|c|}
\hline \multirow[b]{2}{*}{ Reference } & \multirow[b]{2}{*}{$\begin{array}{l}\text { Pumpkin } \\
\text { species }\end{array}$} & \multicolumn{3}{|c|}{ Extraction conditions } & \multirow[b]{2}{*}{$\begin{array}{c}\text { Total } \\
\text { carotenoids } \\
\text { (mg/100 g d.m.) }\end{array}$} \\
\hline & & $\begin{array}{l}\text { Drying } \\
\text { methods }\end{array}$ & $\begin{array}{c}\text { Particle size } \\
\quad \text { (mesh) }\end{array}$ & $\begin{array}{l}\text { Residual } \\
\text { moisture } \\
(\%, w / w)\end{array}$ & \\
\hline Shi et al. [17] & C. moschata & Freeze-drying & 18 & 10 & 10.9 \\
\hline Shi et al. [18] & C. maxima & Freeze-drying & 18 & - & 132.2 \\
\hline \multirow{2}{*}{ Durante et al. [16] } & C. moschata & Vacuum oven & 70 & 12 & 49.2 \\
\hline & C. moschata & Freeze-drying & 70 & 8 & 5.8 \\
\hline
\end{tabular}


Table 3. Effects of temperature, pressure, entrainers and co-matrix on carotenoids composition obtained by $\mathrm{SC}_{-} \mathrm{CO}_{2}$ from pumpkin.

\begin{tabular}{|c|c|c|c|c|c|c|c|c|c|c|c|}
\hline \multirow[b]{2}{*}{ Reference } & \multicolumn{4}{|c|}{ Extraction conditions } & \multicolumn{6}{|c|}{ Carotenoid composition ( $\%$ of total) } & \multirow{2}{*}{$\begin{array}{c}\text { Total carotenoids } \\
\quad(\mathrm{mg} / 100 \mathrm{~g} \\
\text { matrix d.m.) }\end{array}$} \\
\hline & $\begin{array}{c}\text { Temperature } \\
\left({ }^{\circ} \mathrm{C}\right)\end{array}$ & $\begin{array}{c}\text { Pressure } \\
\text { (MPa) }\end{array}$ & Entrainer & Co-matrix & $\begin{array}{l}\text { Lutein and } \\
\text { lutein esters }\end{array}$ & $\begin{array}{c}\alpha- \\
\text { carotene }\end{array}$ & $\begin{array}{c}\beta- \\
\text { cryptoxanthin }\end{array}$ & $\begin{array}{c}\boldsymbol{\beta}- \\
\text { carotene }\end{array}$ & $\begin{array}{l}(9+13-Z)- \\
\beta \text {-carotene }\end{array}$ & Lycopene & \\
\hline \multirow[t]{5}{*}{ Shi et al. [17] } & 40 & 35 & - & - & 41.7 & 14.6 & - & 34.4 & 7.3 & 2.0 & 1.6 \\
\hline & 70 & 35 & - & - & 30.5 & 14.0 & - & 31.0 & 17.9 & 6.6 & 6.1 \\
\hline & 40 & 25 & $10 \% \mathrm{E}$ & - & 33.4 & 15.3 & - & 35.0 & 10.3 & 5.8 & 2.9 \\
\hline & 70 & 25 & $10 \% \mathrm{E}$ & - & 37.6 & 12.0 & - & 31.4 & 12.7 & 6.4 & 9.7 \\
\hline & 70 & 35 & $10 \% \mathrm{E}$ & - & 38.2 & 11.4 & - & 32.8 & 12.5 & 5.2 & 10.9 \\
\hline \multirow[t]{14}{*}{ Shi et al. [18] } & 50 & 25 & - & - & 28.8 & 14.1 & - & 43.3 & 13.7 & - & 132.2 \\
\hline & 50 & 25 & $5 \%-15 \% \mathrm{E}$ & - & $25.8-25.9$ & $14.9-15.6$ & - & $45.5-44.9$ & $13.8-13.6$ & - & $161.9-217.7$ \\
\hline & 50 & 25 & $5 \%-15 \% \mathrm{~W}$ & - & $16.2-25.4$ & $17.4-15.8$ & - & $47.6-45.1$ & $17.1-13.7$ & - & $118.8-179.1$ \\
\hline & 50 & 25 & $5 \%-15 \% \mathrm{O}$ & - & $19.3-28.1$ & $16.9-17.5$ & - & $43.5-42.9$ & $10.5-11.5$ & - & $245.0-254.1$ \\
\hline & 80 & 25 & - & - & 29.3 & 10.3 & - & 35.9 & 24.5 & - & 44.6 \\
\hline & 80 & 25 & $5 \%-15 \% \mathrm{E}$ & - & $31.8-25.9$ & $12.7-15.1$ & - & $34.8-44.9$ & $20.8-14.1$ & - & $60.9-153.9$ \\
\hline & 80 & 25 & $5 \%-15 \% \mathrm{~W}$ & - & $22.8-24.2$ & $14.2-14.3$ & - & $44.8-44.6$ & $18.2-16.3$ & - & $191.5-107.2$ \\
\hline & 80 & 25 & $5 \%-15 \% \mathrm{O}$ & - & $15.2-21.3$ & $19.2-17.7$ & - & $53.4-49.1$ & $12.2-11.9$ & - & $229.2-256.4$ \\
\hline & 50 & 25 & $10 \% \mathrm{~W}+10 \% \mathrm{O}$ & - & 30.9 & 14.9 & - & 44.7 & 9.4 & - & 338.1 \\
\hline & 50 & 25 & $10 \% \mathrm{O}+10 \% \mathrm{E}$ & - & 16.0 & 18.8 & - & 52.1 & 12.9 & - & 285.0 \\
\hline & 50 & 25 & $10 \% \mathrm{~W}+10 \% \mathrm{E}$ & - & 28.03 & 11.9 & - & 44.9 & 15.1 & - & 195.9 \\
\hline & 80 & 25 & $10 \% \mathrm{~W}+10 \% \mathrm{O}$ & - & 28.4 & 16.1 & - & 42.6 & 12.9 & - & 304.9 \\
\hline & 80 & 25 & $10 \% \mathrm{~W}+10 \% \mathrm{E}$ & - & 27.2 & 15.1 & - & 41.7 & 15.9 & - & 99.6 \\
\hline & 80 & 25 & $10 \% \mathrm{E}+10 \% \mathrm{O}$ & - & 22.03 & 13.7 & - & 42.4 & 21.9 & - & 334.8 \\
\hline \multirow[t]{2}{*}{ Durante et al. [16] } & 60 & 35 & - & - & 4.4 & 38.5 & 1.1 & 46.7 & 9.3 & - & 49.2 \\
\hline & 60 & 35 & - & Pumpkin seeds & 5.0 & 33.3 & 0.7 & 55.5 & 5.5 & - & 79.2 \\
\hline
\end{tabular}


Table 4. Comparison of carotenoids composition extracted from pumpkin by organic solvent and $\mathrm{SC}-\mathrm{CO}_{2}$.

\begin{tabular}{|c|c|c|c|c|c|c|c|c|c|c|c|c|}
\hline \multirow[b]{2}{*}{ Reference } & \multicolumn{5}{|c|}{ Extraction conditions } & \multicolumn{6}{|c|}{ Carotenoid composition (\% of total) } & \multirow{2}{*}{$\begin{array}{c}\text { Total carotenoids } \\
\text { (mg/100 g } \\
\text { matrix d.m.) } \\
\end{array}$} \\
\hline & $\begin{array}{c}\text { Temperature } \\
\left({ }^{\circ} \mathrm{C}\right)\end{array}$ & $\begin{array}{c}\text { Pressure } \\
\text { (MPa) }\end{array}$ & $\begin{array}{c}\text { Extraction } \\
\text { methods }\end{array}$ & Entrainer & Co-matrix & $\begin{array}{l}\text { Lutein and } \\
\text { lutein esters }\end{array}$ & $\begin{array}{c}\alpha- \\
\text { carotene }\end{array}$ & $\begin{array}{c}\beta- \\
\text { cryptoxanthin }\end{array}$ & $\begin{array}{c}\beta- \\
\text { carotene }\end{array}$ & $\begin{array}{l}(9+13-Z)- \\
\beta \text {-carotene }\end{array}$ & Lycopene & \\
\hline $\begin{array}{c}\text { Shi } \\
\text { et al. [17] }\end{array}$ & - & - & $\begin{array}{c}\text { Ethanol/hexane } \\
(1 / 1, v / v)\end{array}$ & - & - & 35.4 & 19.7 & - & 41.4 & 3.5 & 0.1 & 14.8 \\
\hline Durante & 69 & 0.1 & Hexane & - & - & 3.2 & 30.9 & 0.4 & 50.3 & 15.2 & - & 81.3 \\
\hline & 69 & 0.1 & Hexane & - & $\begin{array}{l}\text { Pumpkin } \\
\text { seeds }\end{array}$ & 2.6 & 35.1 & 3.4 & 58.8 & nd & - & 84.0 \\
\hline $\begin{array}{c}\text { Shi } \\
\text { et al. [18] }\end{array}$ & - & - & $\begin{array}{c}\text { Ethanol/hexane } \\
(4 / 3, v / v)\end{array}$ & - & - & 27.8 & 20.1 & - & 43.1 & 8.9 & - & 1286.4 \\
\hline
\end{tabular}

nd, not detectable. 


\section{Conclusions}

$\mathrm{SC}-\mathrm{CO}_{2}$ extraction of carotenoids from pumpkin have gained great attention in the last few years. The studies here reviewed show that pumpkin $\mathrm{SC}-\mathrm{CO}_{2}$ extracts are interesting, innovative, and high quality products rich with $\alpha$ - and $\beta$-carotene as well as other bioactive compounds. Optimization of experimental parameters, such as pressure, temperature and moisture of pumkin matrices, and the use of entrainers or oleaginous co-matrix addition, can substantially increase carotenoid extraction yield. Vacuum oven- and freeze-drying pre-treatments gave good results in the preparation of pumpkin matrices suitable for supercritical $\mathrm{CO}_{2}$-extraction. However, vacuum oven-dried matrices gave far better results in terms of carotenoid extraction yield than oven-dried matrices possibly due to tissue and cell structure disaggregation which may increase the permeability of the matrix to the fluid. The best operative conditions for pumpkin carotenoids extraction by $\mathrm{SC}-\mathrm{CO}_{2}$ were found to be: $35 \mathrm{MPa}$, $50-70{ }^{\circ} \mathrm{C}$, for pressure and temperature, respectively. The highest extraction yield was achieved by the combination of water $(10 \%)$ and olive oil $(10 \%)$ or ethanol $(10 \%)$ and olive oil $(10 \%)$, as entrainers, at 50 and $80{ }^{\circ} \mathrm{C}$, respectively. Information on the influence of different seeds, as co-matrix, still require thorough studies.

Although the operation cost of $\mathrm{SC}-\mathrm{CO}_{2}$ remains high and is still difficult to scale up the extraction process to an industrial level, these findings encourage further studies in order to scale up the process for possible industrial production of high quality bioactive ingredients from pumpkin for nutraceutical, cosmeceutical and pharmaceutical preparations. It is also desirable that comparative research trials were undertaken to assay any differences in the biological activity and action mechanisms of carotenoid containing $\mathrm{SC}-\mathrm{CO}_{2}$ extracts from pumpkin compared to those obtained by conventional extraction techniques.

\section{Acknowledgments}

The research has been supported by Ministero dell'Istruzione, dell'Università e della Ricerca (MIUR) Project “Conoscenze Integrate per la Sostenibilità e l' Innovazione del made in Italy Agroalimentare" (CISIA).

\section{Author Contributions}

Durante Miriana wrote the manuscript, Lenucci Salvatore Marcello and Giovanni Mita supervised the work and revised paper.

\section{Conflicts of Interest}

The authors declare no conflict of interest.

\section{References}

1. Bendich, A. Carotenoids and the immune response. J. Nutr. 1989, 119, 112-115.

2. Chew, B.P.; Park, J.S. Carotenoid action on the immune response. J. Nutr. 2004, 134, 257S-261S. 
3. Gamboa-Pinto, A.J.; Rock, C.L.; Ferruzzi, M.G.; Schowinsky, A.B.; Schwartz, S.J. Cervical tissue and plasma concentrations of $\alpha$-carotene and $\beta$-carotene are correlated. J. Nutr. 1988, 128 , 1933-1936.

4. Maiani, G.; Castón, M.J.; Catasta, G.; Toti, E.; Cambrodón, I.G.; Bysted, A.; Granado-Lorencio, F.; Olmedilla-Alonso, B.; Knuthsen, P.; Valoti, M.; et al. Carotenoids: Actual knowledge on food sources, intakes, stability and bioavailability and their protective role in humans. Mol. Nutr. Food Res. 2009, 53, 194-218.

5. Whang, H.J.; Park, Y.K.; Seog, H.M. Carotenoid pigment of pumpkin cultivated in Korea. Korea J. Food Nutr. 1999, 12, 508-512.

6. Doymaz, I. The kinetics of forced convective air-drying of pumpkin slices. J. Food Eng. 2007, 79, 243-248.

7. Guinè, R.P.F.; Henrriques, F.; Barroca, M.J. Mass transfer coefficients for the drying of pumpkin (Cucurbita moschata) and dried product quality. Food Bioprocess Tech. 2012, 5, 176-183.

8. Fu, C.; Shi, H.; Li, Q. A review on pharmacological activities and utilization technologies of pumpkin. Plant Foods Hum. Nutr. 2006, 61, 73-80.

9. Boiteux, L.S.; Nascimento, W.M.; Fonseca, M.E.N.; Lana, M.M.; Reis, A.; Mendonça, J.L.; Lopes, J.F.; Reifschneider, F.J.B. "Brasileirinha": An ornamental bicolor squash (Cucurbita moschata) cultivar for immature fruit consumption. Hortic. Bras. 2007, 25, 103-106.

10. Rodriguez-Amaya, D.B.; Kimura, M.; Godoy, H.T.; Amaya-Farfan, J. Updated Brazilian database on food carotenoids: Factors affecting carotenoids composition. J. Food Compost. Anal. 2008, 21, 445-463.

11. Jacks, T.J.; Hensarling, T.P.; Yatsu, L.Y. Cucurbit seeds: I. Characterizations and uses of oils and proteins. A review. Econ. Bot. 1972, 26, 135-141.

12. Yu, W.; Zhao, Y.; Chen, J.; Shu, B. Comparison of two kinds of pumpkin seed oils obtained by supercritical $\mathrm{CO}_{2}$ extraction. Eur. J. Lipid Sci. Technol. 2004, 106, 355-358.

13. Ptitchkina, N.M.; Danilova, I.A.; Doxastakis, G.; Kasapis, S.; Morris, E.R. Pumpkin pectin: Gel formation at unusually low concentration. Carbohydr. Polym. 1994, 23, 265-273.

14. Yoo, S.H.; Lee, B.H.; Lee, H.; Lee, S.; Bae, I.Y.; Lee, H.G.; Fishman, M.L.; Chau, H.K.; Savary, B.J.; Hotchkiss, A.T. Structural characteristics of pumpkin pectin extracted by microwave heating. J. Food Sci. 2012, 77, 1169-1173.

15. Seo, J.S.; Burri, B.J.; Quan, Z.; Neidlinger, T.R. Extraction and chromatography of carotenoids from Pumpkin. J. Chromatogr. A 2005, 1073, 371-375.

16. Durante, M.; Lenucci, M.S.; D’Amico, L.; Piro, G.; Mita, G. Effect of drying and co-matrix addition on the yield and quality of supercritical $\mathrm{CO}_{2}$ extracted pumpkin (Cucurbita moschata Duch.) oil. Food Chem. 2014, 148, 314-320.

17. Shi, J.; Yi, C.; Ye, X.; Xue, S.; Jiang, Y.; Ma, Y.; Liu, D. Effects of supercritical $\mathrm{CO}_{2}$ fluid parameters on chemical composition and yield of carotenoids extracted from pumpkin. LWT-Food Sci. Technol. 2010, 43, 39-44.

18. Shi, X.; Wu, H.; Shi, J.; Xue, S.J.; Wang, D.; Wang, W.; Cheng, A.; Gong, Z.; Chen, X.; Wang, C. Effect of modifier on the composition and antioxidant activity of carotenoid extracts from pumpkin (Cucurbita maxima) by supercritical $\mathrm{CO}_{2}$. LWT-Food Sci. Technol. 2013, 51, 433-440. 
19. Hulshof, P.J.M.; Xu, C.; van de Bovenkamp, P. Application of a validated method for the determination of pro-Vitamin A carotenoids in Indonesian foods of different maturity and origin. J. Agric. Food Chem. 1997, 45, 1174-1179.

20. Fikselova, M.; Silhar, S.; Marecek, J.; Francakova, H. Extraction of carrot (Daucus carota L.) carotenes under different conditions. Czech J. Food Sci. 2008, 26, 268-274.

21. Rozzi, N.L.; Singh, R.K. Supercritical fluids and the food industry. Compr. Rev. Food Sci. Food Saf. 2002, 1, 33-44.

22. Calvo, M.M.; Dado, D.; Santa-Maria, G. Influence of extraction with ethanol or ethyl acetate on the yield of lycopene, $\beta$-carotene, phytoene and phytofluene from tomato peel powder. Eur. Food Res. Technol. 2007, 224, 567-571.

23. Abbas, K.A.; Mohamed, A.; Abdulamir, A.S.; Abas, H.A. A review on supercritical fluid extraction as new analytical method. Am. J. Biochem. Biotechnol. 2008, 4, 345-353.

24. Lenucci, M.S.; Caccioppola, A.; Durante, M.; Serrone, L.; Rescio, L.; Piro, G.; Dalessandro, G. Optimisation of biological and physical parameters for lycopene supercritical $\mathrm{CO}_{2}$ extraction from ordinary and high-pigment tomato cultivars. J. Sci. Food Agric. 2010, 90, 1709-1718.

25. Durante, M.; Lenucci, M.S.; Rescio, L.; Mita, G.; Caretto, S. Durum wheat by-products as natural sources of valuable nutrients. Phytochem. Rev. 2012, 11, 255-262.

26. Marsili, R.; Callahan, D. Comparison of a liquid solvent extraction technique and supercritical fluid extraction for the determination of alpha- and beta-carotene in vegetables. J. Chromatogr. Sci. 1993, 31, 422-428.

27. Shi, J.; Mittal, G.; Kim, E.; Xue, J. Solubility of carotenoids in supercritical $\mathrm{CO}_{2}$. Food Rev. Int. 2007, 23, 341-371.

28. Reverchon, E.; Donsi, G.; Osseo, L.S. Modeling of supercritical fluid extraction from herbaceous matrices. Ind. Eng. Chem. Res. 1993, 32, 2721-2726.

29. Reverchon, E.; Senatore, F. Supercritical carbon dioxide extraction of chamomile essential oil and its analysis by gas chromatography-mass spectrometry. J. Agric. Food Chem. 1994, 42, 154-158.

30. Gopalakrishnan, N. Studies on the storage quality of $\mathrm{CO}_{2}$-extracted cardamom and clove bud oils. J. Agric. Food Chem. 1994, 42, 796-798.

31. Favati, F.; King, J.W.; Friedrich, J.P.; Eskins, K. Supercritical $\mathrm{CO}_{2}$ extraction of carotene and lutein from leaf protein concentrates. J. Food Sci. 1988, 53, 1532-1536.

32. Jarén-Galán, M.; Nienaber, U.; Schwartz, S.J. Paprika (Capsicum annuum L.) oleoresin extraction with supercritical carbon dioxide. J. Agric. Food Chem. 1999, 47, 3558-3564.

33. Spanos, G.A.; Chen, H.; Schwartz, S.J. Supercritical $\mathrm{CO}_{2}$ extraction of $\beta$-carotene from sweet potatoes. J. Food Sci. 1983, 58, 817-820.

34. Lenucci, M.S.; Caccioppola, A.; Durante, M.; Serrone, L.; de Caroli, M.; Piro, G.; Dalessandro, G. Carotenoid content during tomato (Solanum lycopersicum L.) fruit ripening in traditional and high-pigment cultivars. Ital. J. Food Sci. 2009, 21, 461-472.

35. Katherine, L.S.; Edgar, C.C.; Jerry, W.K.; Luke, R.H.; Julie, C.D. Extraction conditions affecting Supercritical Fluid Extraction (SFE) of lycopene from watermelon. Int. J. Food Sci. Technol. 2008, 99, 7853-7841. 
36. Durante, M.; Lenucci, M.S.; Laddomada, B.; Mita, G.; Caretto, S. Effects of sodium alginate bead encapsulation on the storage stability of durum wheat (Triticum durum Desf.) bran oil extracted by supercritical $\mathrm{CO}_{2}$. J. Agric. Food Chem. 2012, 60, 10689-10695.

37. Jacobo-Valenzuela, N.; Zazueta-Morales, J.J.; Pérez-Castañeda, V.; Camacho-Hernández, I.L.; Gallegos-Infante, J.A.; Rocha-Guzmán, N.E.; González-Laredo, R.F. Rediscovering winter squash (Cucurbita moschata D.) cv. Cehualca as a magic food in Sinaloa State. Revista salud Pública Y Nutri. 2009, 1, 219-219.

38. Dirim, S.N.; Çalıskan, G. Determination of the effect of freeze drying process on the production of pumpkin (Cucurbita moschata) puree powder and the powder properties. J. Food 2012, 37, 203-210.

39. Wang, L.; Weller, C.L. Recent advances in extraction of nutraceuticals from plants. Trends Food Sci. Technol. 2006, 17, 300-312.

40. Fattori, M.; Bulley, N.R.; Meisen, A. Carbon dioxide extraction of canola seed: Oil solubility and effect of seed treatment. J. Am. Oil Chem. Soc. 1988, 65, 968-974.

41. Liu, C.; Zhong, M.; Shen, Z. Extraction of wheat germ oil by supercritical carbon dioxide. Food Sci. Sin. 1994, 3, 14-17.

42. Ge, Y.; Yang, H.; Hui, B.; Ni, Y.; Wang, S.; Cai, T. Extraction of natural Vitamin E from wheat germ by supercritical carbon dioxide. J. Agric. Food Chem. 2002, 50, 685-689.

43. Wang, S.M.; Yu, D.J.; Song, K.B. Physicochemical property of pumpkin slices dehydrated with red algae extract. J. Korean Soc. Appl. Biol. Chem. 2011, 54, 921-925.

44. Nawirska, A.; Figiel, A.; Kucharska, A.Z.; Letowska, A.S.; Biesiada, A. Drying kinetics and quality parameters of pumpkin slices dehydrated using different methods. J. Food Eng. 2009, 94, $14-20$.

45. Pinedo, A.A.; Murr, F.E.X. Influence of pre-treatments on the drying kinetics during vacuum drying of carrot and pumpkin. J. Food Eng. 2007, 80, 152-156.

46. Doymaz, I. Thin-layer drying behavior of mint leaves. J. Food Eng. 2006, 74, 370-375.

47. Guinè, R.P.F.; Pinho, S.; Barroca, M.J. Study of the convective drying of pumpkin (Cucurbita maxima). Food Bioprod. Process. 2011, 89, 422-428.

48. Que, F.; Mao, L.; Fang, X.; Wu, T. Comparison of hot air-drying and freeze-drying on the physicochemical properties and antioxidant activities of pumpkin (Cucurbita moschata Duch.) flours. Int. J. Food Sci. Technol. 2008, 43, 1195-1201.

49. Sojak, M.; Glowacki, S. Analysis of giant pumpkin (Cucurbita maxima) drying kinetics in various technologies of convective drying. J. Food Eng. 2010, 99, 323-329.

50. Fernando, W.J.N.; Low, H.C.; Ahmad, A.L. Dependence of the effective diffusion coefficient of moisture with thickness and temperature in convective drying of sliced materials. A study on slices of banana, cassava and pumpkin. J. Food Eng. 2011, 102, 310-316.

51. Perez, N.E.; Schmalko, M.E. Convective drying of pumpkin: Influence of pretreatment and drying temperature. J. Food Process Eng. 2009, 32, 88-103.

52. Wang, J.; Wang, J.S.; Yu, Y. Microwave drying characteristics and dried quality of pumpkin. Int. J. Food Sci. Technol. 2007, 42, 148-156.

53. Alibas, I. Microwave, air and combined microwave-Air-drying parameters of pumpkin slices. LWT-Food Sci. Technol. 2007, 40, 1445-1451. 
54. Lee, J.S.; Lim, L.S. Osmo-dehydration pretreatment for drying of pumpkin slice. Int. Food Res. J. 2011, 18, 1223-1230.

55. Mayor, L.; Moreira, R.; Sereno, A.M. Shrinkage, density, porosity and shape changes during dehydration of pumpkin (Cucurbita pepo L.) fruits. J. Food Eng. 2011, 103, 29-37.

56. Garcia, C.C.; Mauro, M.A.; Kimura, M. Kinetics of osmotic dehydration and air-drying of pumpkins (Cucurbita moschata). J. Food Sci. 2007, 82, 284-291.

57. Gonçalves, E.M.; Pinheiro, J.; Abreu, M.; Brandão, T.R.S.; Silva, C.L.M. Modelling the kinetics of peroxidase inactivation, colour and texture changes of pumpkin (Cucurbita maxima L.) during blanching. J. Food Eng. 2007, 81, 693-701.

58. Ratti, C. Hot air and freeze-drying of high-value foods: A review. J. Food Eng. 2001, 49, 311-319.

59. Gutiérrez, L.F.; Ratti, C.; Belkacemi, K. Effects of drying method on the extraction yields and quality of oils from quebec sea buckthorn (Hippophae rhamnoides L.) seeds and pulp. Food Chem. 2008, 106, 896-904.

60. Snyder, J.M.; Friedrich, J.P.; Christianson, D.D. Effect of moisture and particle size on the extractability of oils from seeds with supercritical $\mathrm{CO}_{2}$. J. Am. Oil Chem. Soc. 1984, 61, 1851-1856.

61. Cordero, B.; Voltolina, D. Viability of mass algal cultures preserved by freezing and freeze-drying. Aquac. Eng. 1997, 16, 205-211.

62. Rossignol, N.; Vandanjon, L.; Jaouen, P.; Quéméneur, F. Membrane technology for the continuous separation microalgae/culture medium: Compared performances of cross-flow microfiltration and ultrafiltration. Aquac. Eng. 1999, 20, 191-208.

63. Goto, M.; Sato, M.; Hirose, T. Supercritical Carbon Dioxide Extraction of Carotenoids from Carrots. In Developments in Food Engineering-Proceedings of the Sixth International Congress on Engineering and Food; Yano, T., Matsuno, R., Nakamura, K., Eds.; Springer US: New York, NY, USA, 1994; pp. 835-837.

64. Baysal, T.; Ersus, S.; Starmans, D.A.J. Supercritical $\mathrm{CO}_{2}$ extraction of $\beta$-carotene and lycopene from tomato paste waste. J. Agric. Food Chem. 2000, 48, 5507-5511.

65. Eggers, R. Supercritical fluid extraction (SFE) of oilseeds/lipids in natural products. In Supercritical Fluid Technology in Oil and Lipid Chemistry; King, J.W., List, G.R., Eds.; AOCS Press: Urbana, IL, USA, 1996; pp. 35-65.

66. Reverchon, E.; de Marco, I. Supercritical fluid extraction and fractionation of natural matter. J. Supercrit. Fluids 2006, 38, 146-166.

67. Shi, J.; Khatri, M.; Xue, S.J.; Mittal, G.S.; Ma, Y.; Li, D. Solubility of lycopene in supercritical $\mathrm{CO}_{2}$ fluid as affected by temperature and pressure. Sep. Purif. Technol. 2009, 66, 322-328.

68. Shi, J.; Dai, Y.; Kakuda, Y.; Mittal, G.; Xue, J. Effect of heating and light irradiation on the stability of lycopene in tomato puree. Food Control. 2008, 19, 514-520.

69. Fhamy, T.M.; Paulaitis, M.E.; Johnson, D.N.; McNally, A.E.P. Modifier effects in supercritical fluids extraction of solutes from clay, soy, and plant materials. Anal. Chem. 1993, 65, 1462-1469.

70. Machmudaha, S.; Zakaria; Winardi, S.; Sasaki, M.; Goto, M.; Kusumoto, N.; Hayakawa, K. Lycopene extraction from tomato peel by-product containing tomato seed using supercritical carbon dioxide. J. Food Eng. 2012, 108, 290-296. 
71. Vasapollo, G.; Longo, L.; Rescio, L.; Ciurlia, L. Innovative supercritical $\mathrm{CO}_{2}$ extraction of lycopene from tomato in the presence of vegetable oil as cosolvent. J. Supercrit. Fluids 2004, 29, 87-96.

72. Ciurlia, L.; Bleve, M.; Rescio, L. Supercritical carbon dioxide co-extraction of tomatoes (Lycopersicum esculentum L.) and hazelnuts (Corylus avellana L.): A new procedure in obtaining a source of natural lycopene. J. Supercrit. Fluids 2009, 49, 338-344.

73. Longo, C.; Leo, L.; Leone, A. Carotenoids, Fatty acid composition and heat stability of supercritical carbon dioxide-extracted-oleoresins. Int. J. Mol. Sci. 2012, 13, 4233-4254.

74. Casas, L.; Mantell, C.; Rodríguez, M.; Torres, A.; Macías, F.A.; de la Ossa, E.M. Effect of the addition of cosolvent on the supercritical fluid extraction of bioactive compounds from Helianthus annuus L. J. Supercrit. Fluids 2007, 41, 43-49.

75. Chiu, K.L.; Cheng, Y.C.; Chen, J.H.; Chang, C.J.; Yang, P.W. Supercritical fluids extraction of Ginkgo ginkgolides and flavonoids. J. Supercrit. Fluids 2002, 24, 77-87.

76. De Lucas, A.; Gracia, I.; Rincon, J.; Garcia, M.T. Solubility determination and model prediction of Olive Husk oil in supercritical carbon dioxide and co-solvents. Ind. Eng. Chem. Res. 2007, 46, 5061-5066.

77. Sanal, I.S.; Bayraktar, E.; Mehmetoglu, U.; Calıml1, A. Determination of optimum conditions for $\mathrm{SC}-\left(\mathrm{CO}_{2}+\right.$ ethanol) extraction of $\beta$-carotene from apricot pomace using response surface methodology. J. Supercrit. Fluids 2005, 34, 331-338.

78. Güçlü-Üstündag, Ö.; Temeli, F. Solubility behavior of ternary systems of lipids, cosolvents and supercritical carbon dioxide and processing aspects. J. Supercrit. Fluids 2005, 36, 1-15.

79. Sun, M.; Temelli, F. Supercritical carbon dioxide extraction of carotenoids from carrot using canola oil as a continuous co-solvent. J. Supercrit. Fluids 2006, 37, 397-408.

80. Leibovitz, B.; Hu, M.L.; Tappel, A.L. Dietary supplements of vitamin E, beta-carotene, coenzyme Q10 and selenium protect tissue against lipid peroxidation in rat tissue slices. J. Nutr. 1990, 120, 97-104.

81. Handelman, G.J.; van Kuijk, F.J.G.M.; Chatterjee, A.; Krinsky, N.I. Characterization of products formed during the autoxidation of $\beta$-carotene. Free Radic. Biol. Med. 1991, 10, 427-437.

82. Palozza, P.; Krinsky, N.I. Antioxidant effects of carotenoids in vivo and in vitro: An overview. Meth. Enzymol. 1992, 213, 403-420.

83. Levin, G.; Mokady, S. Antioxidant activity of 9-cis compared to all-trans $\beta$-carotene in vitro. Free Radic. Biol. Med. 1994, 17, 77-82.

84. Jimenéz, C.; Pick, U. Differential reactivity of $\beta$-carotene isomers from Dunaliella bardawil toward oxygen radicals. Plant Physiol. 1993, 101, 385-390.

85. Böhm, V.; Puspitasari-Nienaber, L.N.; Ferruzzi, M.G.; Schwartz, S.J. Trolox equivalent antioxidant capacity of different geometrical isomers of $\alpha$-carotene, $\beta$-carotene, lycopene, and zeaxanthin. J. Agric. Food Chem. 2002, 50, 221-226.

(C) 2014 by the authors; licensee MDPI, Basel, Switzerland. This article is an open access article distributed under the terms and conditions of the Creative Commons Attribution license (http://creativecommons.org/licenses/by/3.0/). 